\title{
Identification of a 43-kDa outer-membrane protein as an adhesin in Aeromonas caviae
}

\author{
C. M. ROCHA-DE-SOUZA, A. V. COLOMBO, R. HIRATA, A. L. MATTOS-GUARALDI, \\ L. H. MONTEIRO-LEAL*, J. O. PREVIATO†, A. C. FREITAS and A. F. B. ANDRADE
}

Departamento de Microbiologia e Imunologia, Faculdade de Ciências Médicas, *Departamento de Histologia e Embriologia, Instituto de Biologia, Universidade do Estado do Rio de Janeiro, Av. 28 de Setembro, 87 -Fundos, $3^{\circ}$ andar, Vila Isabel, RJ 20551-030 and †Departamento de Microbiologia Geral, Instituto de Microbiologia Prof. Paulo de Góes, Universidade Federal do Rio de Janeiro, CCS, Bloco I, Ilha do Fundão, RJ, Brazil

\begin{abstract}
Aeromonas spp. are associated with intestinal and extra-intestinal infections. However, the virulence factors of $A$. caviae remain, for the most part, poorly known. This study examined the interactions involved in the adherence of $A$. caviae isolates Ae56, Ae391 and Ae398 to HEp-2 cells. All strains expressed high levels of aggregative adherence. Maximum adhesion occurred with bacteria grown at $22^{\circ} \mathrm{C}$, but transmission electron microscopy did not reveal the presence of fimbrial structures on the bacterial cell surface. Outer-membrane proteins (OMPs) extracted from isolate Ae398, grown at $22^{\circ} \mathrm{C}$ and $37^{\circ} \mathrm{C}$, showed similar SDS-PAGE protein profiles. Most proteins were $<60 \mathrm{kDa}$. A major 43-kDa protein was seen only in the boiled OMP extract. The biotinylated 43-kDa protein bound specifically to HEp-2 cells. Microbeads coated with the 43-kDa protein were also adherent to HEp-2 cells, and anti-43-kDa protein antibody blocked adherence of 43-kDa protein-coated latex beads. These data suggest that the 43-kDa OMP functions as an adhesin in $A$. caviae.
\end{abstract}

\section{Introduction}

Aeromonas spp. comprise a widespread group of gramnegative bacteria that can be isolated from many sources such as food, drinking water, sewage, environmental water and human clinical specimens [1-3]. Virulence mechanisms are not well understood and confusion over the taxonomy of the genus has compounded difficulties in the identification of potential disease-causing strains. However, substantial evidence points to Aeromonas spp. as the causative agents of sporadic diarrhoea, dysentery and extra-intestinal infections that may be life-threatening $[4,5]$. Two hybridisation groups (HGs), A. hydrophila (HG1) and A. veronii biovar sobria (HG8) were thought to be the main causes of aeromonas-associated illness. However, some investigations also implicate $A$. caviae (HG4) as a significant enteropathogen $[6,7]$. It has been recognised that adherence to host cells is an important step in the pathogenesis of enteropathogenic bacteria, including Aeromonas spp. [8-11]. Although recent studies indicate that some filamentous structures, outer-

Received 12 June 2000; accepted 14 Sept. 2000.

Corresponding author: Dr A.F.B. Andrade (e-mail: arnaldo @uerj.br). membrane proteins (OMPs) and lipopolysaccharide (LPS) could be intestinal adhesins, the colonisation mechanisms of enteropathogenic Aeromonas strains are poorly characterised, especially in A caviae [12-15]. The pili of aeromonads have been described by morphological criteria as short, rigid $(\mathrm{S} / \mathrm{R})$ and long, wavy (L/W) structures. S/R pili are common and numerous among environmental isolates. In contrast, $\mathrm{L} / \mathrm{W}$ pili are few in number, but are the dominant type observed on clinical strains [8]. L/W pili have been identified as aeromonas colonisation factors and also as haemagglutinins $[12,13]$. Furthermore, an A6-type haemagglutinin (Ae-HAG) from A. hydrophila has been reported as a possible colonisation factor. A6$\mathrm{HAG}$ is a $43-\mathrm{kDa}$ OMP that binds to $\mathrm{H}$ antigen expressed on the surface of most human erythrocytes $[16,17]$. In this study OMPs were investigated as possible colonisation factors in $A$. caviae adherence to HEp-2 cells.

\section{Materials and methods}

Bacterial strains and culture conditions

Three clinical isolates of $A$. caviae (Ae56, Ae391 and Ae398) from children with gastro-enteritis were studied. They were isolated in the Bacteriology Department 
at the Pedro Ernestro Hospital of Rio de Janeiro University [18]. A. hydrophila strain Ae7 was chosen to serve as a fimbriate control. Escherichia coli DH5 $\alpha$ (K12) was included in this study as a non-adherent avirulent negative control. Long-term storage of strains was in skim milk (Difco, Detroit, MI, USA) at $-70^{\circ} \mathrm{C}$ and short-term storage was in minimal maintenance medium at $15^{\circ} \mathrm{C}$. The $A$. hydrophila and E. coli strains were cultured in Tryptic Soy Broth (TSB, Difco) at $22^{\circ} \mathrm{C}$ for $48 \mathrm{~h}$ and at $37^{\circ} \mathrm{C}$ for $24 \mathrm{~h}$, respectively. The $A$. caviae strains were subcultured from $-70^{\circ} \mathrm{C}$ storage on to blood agar and incubated at $37^{\circ} \mathrm{C}$ overnight. A sweep of colonies was inoculated into TSB without glucose and incubated at $37^{\circ} \mathrm{C}$ for $24 \mathrm{~h}$ or at $22^{\circ} \mathrm{C}$ for $48 \mathrm{~h}$ [19]. For OMP purification, a broth culture was used to inoculate $6 \mathrm{~L}$ of TSB which was incubated statically at $22^{\circ} \mathrm{C}$ or $37^{\circ} \mathrm{C}$. For adherence assays, the culture density was estimated both by serial dilution and plating on to Mueller-Hinton Agar (Difco) for viable counting, and by the measurement of OD at $640 \mathrm{~nm}$.

\section{Adhesion to HEp-2 cells}

HEp-2 cells (ATCC CCL23), derived from human epidermoid larynx carcinoma, were grown under standard conditions in air with $\mathrm{CO}_{2} 5 \%$ at $37^{\circ} \mathrm{C}$ in Eagle's Minimal Essential Medium (MEM, Sigma) supplemented with fetal calf serum (FCS; Gibco BRL, NY, USA) $5 \%$. For the qualitative adhesion assay, HEp2 cells were grown to semi-confluency for $24 \mathrm{~h}$ on circular glass coverslips (diameter $12 \mathrm{~mm}$ ) in 24-well tissue-culture plates (Nalge Nunc International, Denmark). Bacteria grown in TSB at $22^{\circ} \mathrm{C}$ or $37^{\circ} \mathrm{C}$ were harvested by low speed centrifugation, washed twice in $10 \mathrm{mM}$ Na-phosphate-buffered saline, pH 7.4 (PBS) and resuspended in MEM containing FCS 5\%. One $\mathrm{ml}$ of bacterial suspension, containing $10^{7} \mathrm{cfu}\left(\mathrm{OD}_{640} 0.2\right)$, was added to duplicate coverslip cultures of HEp-2 cells. The infected monolayers were incubated at $37^{\circ} \mathrm{C}$ for $90 \mathrm{~min}$ in air with $\mathrm{CO}_{2} 5 \%$. Non-adherent bacteria were removed from monolayers by washing three times with PBS. The cells were fixed with methanol:acetic acid $(3: 1)$ for $15 \mathrm{~min}$ and stained with Giemsa $10 \%$ for $1 \mathrm{~h}$. The coverslips were mounted on glass slides and viewed by light microscopy [8]. For the quantitative adhesion assay, HEp-2 cells were grown to confluency for $48 \mathrm{~h}$ in 24-well tissue-culture plates. Bacterial suspensions, prepared as described above, were inoculated on to the HEp-2 monolayers. After incubation at $37^{\circ} \mathrm{C}$ for $90 \mathrm{~min}$ in air with $\mathrm{CO}_{2} 5 \%$, the monolayers were washed three times with PBS. Then $200 \mu \mathrm{l}$ of Triton X-100 1\% in PBS were added to each well and the plates were rocked at $37^{\circ} \mathrm{C}$ for $30 \mathrm{~min}$. MEM $(800 \mu \mathrm{l})$ was added and pipetted up and down vigorously to thoroughly mix the bacteria and lyse the HEp-2 cells. The suspensions were diluted serially in PBS and plated on to Mueller-Hinton Agar to determine the number of cell-associated bacteria. Adherence was expressed as the percentage of the inoculum recovered from the HEp-2 cells after incubation for $90 \mathrm{~min}$.

\section{OMP extraction}

For OMP extraction, A. caviae Ae398 was grown at both $22^{\circ} \mathrm{C}$ for $48 \mathrm{~h}$ and $37^{\circ} \mathrm{C}$ for $24 \mathrm{~h}$. The cultures were centrifuged at low speed for $15 \mathrm{~min}$ at $4^{\circ} \mathrm{C}$. The bacterial pellet was resuspended in $70 \mathrm{ml}$ of a solution containing $10 \mathrm{~mm}$ Tris- $\mathrm{HCl}, \mathrm{pH} 7.8,5 \mathrm{~mm}$ EDTA, $\mathrm{pH} 7.8$, and $1 \mathrm{mM} \beta$-mercaptoethanol (Sigma). The cells were disrupted by four 15 -s bursts at the full power of an ultrasonic disintegrator. Cell debris was removed by low-speed centrifugation $(2000 \mathrm{~g}, 20 \mathrm{~min})$ and membranes were pelleted from the supernatant fraction by centrifugation at $100000 \mathrm{~g}$ for $1 \mathrm{~h}$ at $4^{\circ} \mathrm{C}$. The membrane pellet was resuspended in $20 \mathrm{ml}$ of Sarkosyl (Sigma) $0.5 \%$ and $1 \mathrm{mM} \beta$-mercaptoethanol in distilled water and incubated at $4{ }^{\circ} \mathrm{C}$ overnight. The suspension was then centrifuged at $100000 \mathrm{~g}$ for $1 \mathrm{~h}$ at $4^{\circ} \mathrm{C}$ and the final outer-membrane pellet was resuspended in $10 \mathrm{mM}$ Tris- $\mathrm{HCl}$ buffer, $\mathrm{pH} 7.8$ [19]. The protein content of the OMP suspension was determined by the modified method of Lowry [20] with bovine serum albumin (BSA, Sigma) as standard.

\section{Biotinylation of OMPS}

The OMPs were dialysed against $100 \mathrm{mM}$ sodium bicarbonate solution ( $\mathrm{pH} 9.0$ ) at $4^{\circ} \mathrm{C}$ overnight, then $10 \mu \mathrm{l}$ of $100 \mathrm{~mm}$ biotin (Sigma) were added to $1 \mathrm{ml}$ of OMP solution $(1 \mathrm{mg} / \mathrm{ml})$ at $4^{\circ} \mathrm{C}$ for $1 \mathrm{~h}$. The OMP solution was then dialysed against $\mathrm{PBS}$ at $4^{\circ} \mathrm{C}$ overnight [21].

\section{HEp-2 cell-associated biotinylated OMP assay}

Biotinylated OMP solution prepared as described above was added to confluent HEp-2 monolayers in a 24-well tissue-culture plate. After incubation for $90 \mathrm{~min}$ at $37^{\circ} \mathrm{C}$ in air with $\mathrm{CO}_{2} 5 \%$, the monolayers were washed three times in PBS. Lysis buffer $(200 \mu \mathrm{l}) \mathrm{pH} 7.5$ $25 \mathrm{mM}$ Tris- $\mathrm{HCl}, 250 \mathrm{mM} \mathrm{NaCl}, 5 \mathrm{~mm}$ EDTA, $1 \mathrm{mM}$ $\mathrm{MgCl}_{2}$, phenylmethylsulphonylfluoride (PMSF) $100 \mu \mathrm{g} / \mathrm{ml}$ and Igepal (Sigma) $0.1 \%$ - were added to each well and rocked at $4^{\circ} \mathrm{C}$ for $30 \mathrm{~min}$. The lysed cells were removed by centrifugation at $5000 \mathrm{~g}$ at $4^{\circ} \mathrm{C}$ for $15 \mathrm{~min}$. The supernate was submitted to SDS-PAGE and analysed by the Western blot technique.

\section{SDS-PAGE and Western blot analysis}

SDS-PAGE was performed as described by Laemmli [22] with a discontinuous acrylamide $10 \%$ gel (Miniprotean II, BioRad). Five $\mu$ l of OMP extract $(1 \mathrm{mg} / \mathrm{ml})$ or $5 \mu \mathrm{l}$ of HEp-2 cell-associated biotinylated OMPs $(1 \mathrm{mg} / \mathrm{ml})$ were mixed with an equal volume of $2 \times$ SDS-PAGE sample buffer $(125 \mathrm{mM}$ Tris-HCl, SDS $4 \%$, glycerol $20 \%, \beta$-mercaptoethanol $2 \%$, bromophenol blue $0.002 \%$ ) and boiled for $5 \mathrm{~min}$ before 
electrophoresis. Separated proteins in the gel were stained with Coomassie Brillant Blue in methanol 40\%, acetic acid $10 \%$ in distilled water. In some analyses, the OMPs were mixed within $2 \times$ SDS-PAGE sample buffer without $\beta$-mercaptoethanol and were not boiled. After SDS-PAGE, HEp-2 cell-associated biotinylated OMPs were transferred to a nitrocellulose membrane in a Mini-Transblot Cell (BioRad) by electrophoresis in running buffer, $\mathrm{pH} 8.3$ (25 mM Tris, $192 \mathrm{mM}$ glycine, SDS 1\%) for $90 \mathrm{~min}$ at $100 \mathrm{mV} / 400 \mathrm{~mA}$ [23]. Membranes were blocked with skim milk $5 \%$ in Trisbuffered saline, pH 7.5 (TTBS; $20 \mathrm{mM}$ Tris, $500 \mathrm{mM}$ $\mathrm{NaCl}$, Tween-20 $0.05 \%$ ) for $2 \mathrm{~h}$, washed three times in TTBS and incubated with 1 in 5000 streptavidinperoxidase (Sigma) for $30 \mathrm{~min}$. After washing, they were developed in a solution of $\mathrm{H}_{2} \mathrm{O}_{2} \quad 0.3 \%, 3-3^{\prime}$ diaminobenzidine $1 \mathrm{mg} / \mathrm{ml}$, imidazole (Sigma) $1 \mathrm{mg} / \mathrm{ml}$.

\section{3-kDa OMP isolation and antibody production}

SDS-PAGE of OMP extract ( $500 \mu \mathrm{g})$ was performed as described above. The $43-\mathrm{kDa}$ protein was cut out and eluted from gel slices with a Electro-Eluter (Model 422, BioRad) and the running buffer, $\mathrm{pH} 8.3$, at $20 \mathrm{~mA}$ for $6 \mathrm{~h}$. The $43-\mathrm{kDa}$ protein concentration was assayed as described previously [20]. A New Zealand White rabbit was immunised by multiple subcutaneous injections with $150 \mu \mathrm{g}$ of purified 43-kDa OMP emulsified with complete Freund's adjuvant (Sigma). Subsequently, three intramuscular injections were given weekly in incomplete Freund's adjuvant (Sigma). The rabbit was bled directly via the heart at day 10 after the last injection. The antiserum was pooled and stored at $-20^{\circ} \mathrm{C}$ until used [24]. The IgG fraction of the antiserum was obtained by multiple salting out with $33 \%$ saturated ammonium sulphate and purified on a column of Superose (10/30) by high-performance liquid chromatography (HPLC; Pharmacia LKB Biotechnology, Uppsala, Sweden) [25]. The purification procedure was monitored by SDS-PAGE analysis and the concentration of $\mathrm{IgG}$ antibody was determined by absorbance at $280 \mathrm{~nm}$. The specificity of the IgG for the 43-kDa OMP was checked by the Ouchterlony immunodiffusion method [25].

\section{HEp-2 cell-associated 43-kDa OMP assay}

Carboxylated microspheres $\left(1 \mu \mathrm{m}^{3}\right.$, Sigma $)$ were coated with the 43-kDa OMP or BSA. The concentration of coated beads was $c .1 .8 \times 10^{10}$ beads $/ \mathrm{ml}$, and the amounts of $43-\mathrm{kDa}$ OMP and BSA bound to each microsphere were estimated as $20 \mathrm{fg}$ [26]. Then, $50 \mu \mathrm{l}$ of a suspension of protein-coated beads were added to HEp-2 semi-confluent monolayers in 24-well tissue culture plates. After incubation at $37^{\circ} \mathrm{C}$ for $90 \mathrm{~min}$ in air with $\mathrm{CO}_{2} 5 \%$, non-adherent beads were removed from monolayers by washing three times in PBS. The cells were fixed with glutaraldehyde (Merck) $0.2 \%$ and viewed by light microscopy. For adherence inhibition assays, $\quad 43-\mathrm{kDa}$ OMP-coated beads $\left(1.8 \times 10^{10}\right.$ beads $/ \mathrm{ml}$ ) were pretreated with anti-43-kDa OMP antibody $(200 \mu \mathrm{g} / \mathrm{ml})$ at $37^{\circ} \mathrm{C}$ for $1 \mathrm{~h}$ and added to the HEp-2 cell monolayers. In the other assay, HEp-2 cells were pretreated with OMP solution $(1 \mathrm{mg} / \mathrm{ml})$ and exposed to the $43-\mathrm{kDa}$ OMP-coated beads. The adhesion assays were performed as described above.

\section{Electron microscopy}

All three $A$. caviae strains were examined for the presence of fimbriae by transmission electron microscopy (TEM). Cell suspensions were fixed in phosphate-buffered glutaraldehyde $0.2 \%\left(\mathrm{pH} \mathrm{7.2)}\right.$ at $4^{\circ} \mathrm{C}$ for $15 \mathrm{~min}$ and a drop was placed on formvar-coated copper grids (150 mesh, Sigma) for $5 \mathrm{~min}$. The grids were negatively stained with potassium phosphotungstate $1 \%$, washed with water for $1 \mathrm{~min}$, dried and then viewed in a Zeiss 906 transmission electron microscope. For immunolabelling, the grids were inoculated in the presence of BSA $5 \% \mathrm{w} / \mathrm{v}$ in Tris buffer, $\mathrm{pH} 8.2$ ( $20 \mathrm{mM}$ Tris, Tween $200.05 \%$ ) for $30 \mathrm{~min}$ to prevent non-specific labelling, and then treated with anti-43$\mathrm{kDa}$ OMP antibody ( 1 in 40 dilution) for $1 \mathrm{~h}$ at room temperature, washed three times in PBS and then incubated in the presence of $5 \mathrm{~nm}$ gold-labelled goat anti-rabbit IgG ( 1 in 20 dilution) for $30 \mathrm{~min}$ at room temperature. After incubation, the grids were washed in the same buffer, negatively stained as before and viewed as above. Grids treated with pre-immune serum ( 1 in 40 dilution) were used as a control.

\section{Results}

\section{Non-fimbrial adherence to HEp-2 cells}

A. caviae isolates (Ae56, Ae391, Ae398) showed a higher percentage of adherence than E. coli DH5 $\alpha$ to HEp-2 cells (Table 1). All isolates formed small clusters of aggregated bacteria ( $\geqslant 10$ bacteria/cell) on the cell surface. Bacterial aggregates adhered to cell monolayers with a typical 'stacked-brick' appearance (Fig. 1). All the A. caviae isolates were more adherent to HEp-2 cells when the bacteria were grown at $22^{\circ} \mathrm{C}$ than when they were grown at $37^{\circ} \mathrm{C}$. In quantitative assays, a mean of $32.5 \%$ and $3.4 \%$ of the initial inoculum of strains grown at $22^{\circ} \mathrm{C}$ and $37^{\circ} \mathrm{C}$, respectively, adhered to $\mathrm{HEp}-2$ cells after incubation for $30 \mathrm{~min}$ (Table 1). The results of electron microscopy showed that all the A. caviae isolates, whether grown at $37^{\circ} \mathrm{C}$ or $22^{\circ} \mathrm{C}$, did not form fimbrial structures on the bacterial cell surface when compared with the fimbriate control $A$. hydrophila Ae7. Fig. 2 shows an electron micrograph of $A$. caviae isolate Ae398 grown at $22^{\circ} \mathrm{C}$ for $48 \mathrm{~h}$.

\section{Purification of OMPs and binding to HEp-2 cells}

Preparation of OMPs by the Sarkosyl method was found to be effective for the A. caviae isolates; c. 10- 
Table 1. Comparison of adherence of $A$. caviae strains grown at $22^{\circ} \mathrm{C}$ and $37^{\circ} \mathrm{C}$ to HEp-2 cells

\begin{tabular}{|c|c|c|}
\hline \multirow[b]{2}{*}{ Strain* no. } & \multicolumn{2}{|c|}{ Mean bacterial count (cfu/cell monolayer) at } \\
\hline & $22^{\circ} \mathrm{C}$ & $37^{\circ} \mathrm{C}$ \\
\hline $\begin{array}{l}\text { Ae56 } \\
\text { Ae391 } \\
\text { A398 } \\
\text { E. coli } \text { DH5 } \alpha^{*}\end{array}$ & $\begin{array}{c}\text { 2.7 SD } 0.1 \times 10^{6}(27 \%)^{\dagger} \\
3.2 \mathrm{SD} 0.2 \times 10^{6}(32 \%) \\
3.85 \mathrm{SD} 0.05 \times 10^{6}(38.5 \%) \\
\mathrm{NT}\end{array}$ & $\begin{array}{r}2.95 \text { SD } 0.05 \times 10^{5}(2.95 \%) \\
3.25 \text { SD } 0.01 \times 10^{5}(3.25 \%) \\
4.05 \text { SD } 0.05 \times 10^{5}(4.05 \%) \\
4.7 \text { SD } 0.1 \times 10^{4}(0.47 \%)\end{array}$ \\
\hline
\end{tabular}

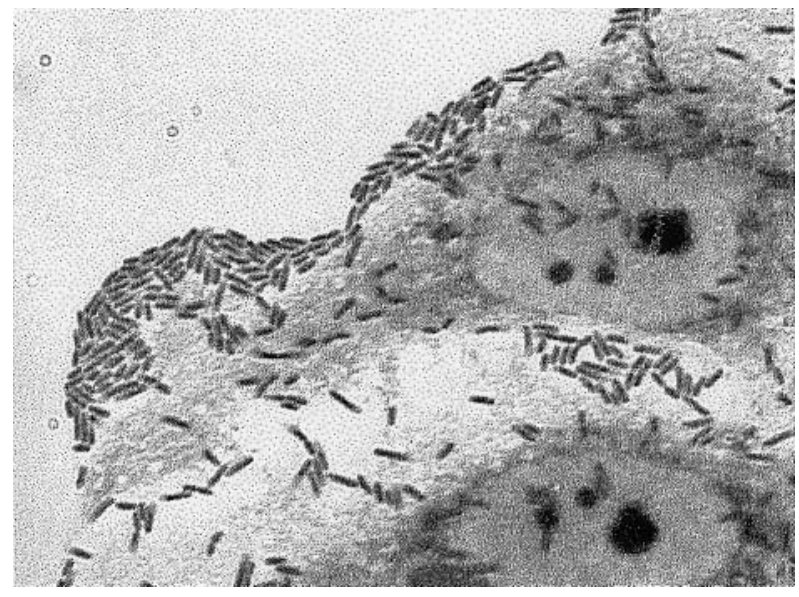

Fig. 1. Aggregative adherence of A. caviae isolate Ae398 to HEp-2 cells showing a stacked-brick appearance on the cell surface. Light microscopy $\times 550$.

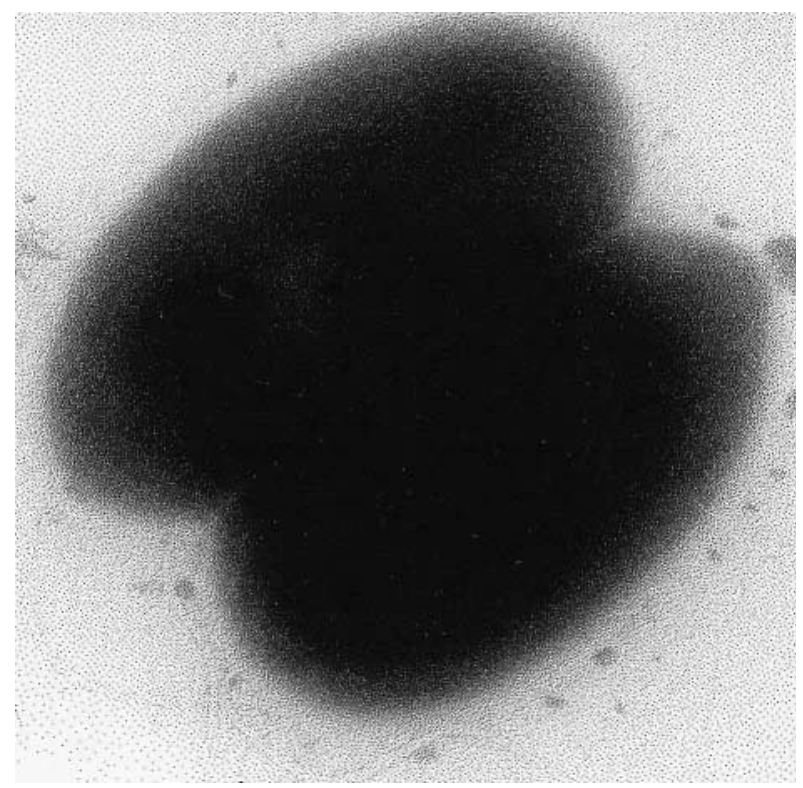

Fig. 2. TEM of negatively stained $A$. caviae isolate Ae398 grown under fimbrial expression conditions $\left(22^{\circ} \mathrm{C}\right.$ for $\left.48 \mathrm{~h}\right)$. No fimbrial structures are seen on the bacterial cell surface.
$20 \mathrm{mg}$ and 2-4 $\mathrm{mg}$ of OMPs were obtained from $6 \mathrm{~L}$ of bacterial culture incubated at $22^{\circ} \mathrm{C}$ for $48 \mathrm{~h}$ and at $37^{\circ} \mathrm{C}$ for $24 \mathrm{~h}$, respectively. No qualitative differences were observed in the OMP profiles by SDS-PAGE of A.caviae Ae398 grown at $22^{\circ} \mathrm{C}$ or $37^{\circ} \mathrm{C}$ (Fig. 3a).

a

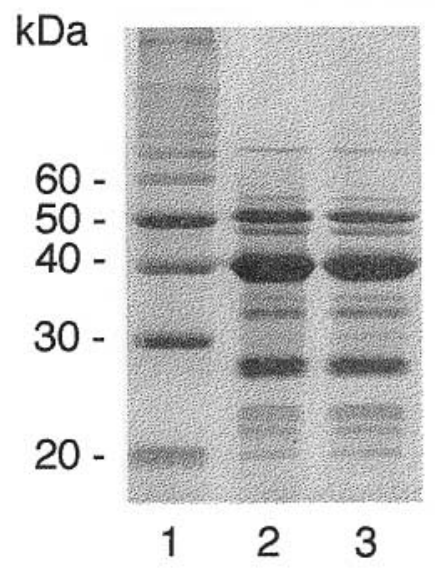

b

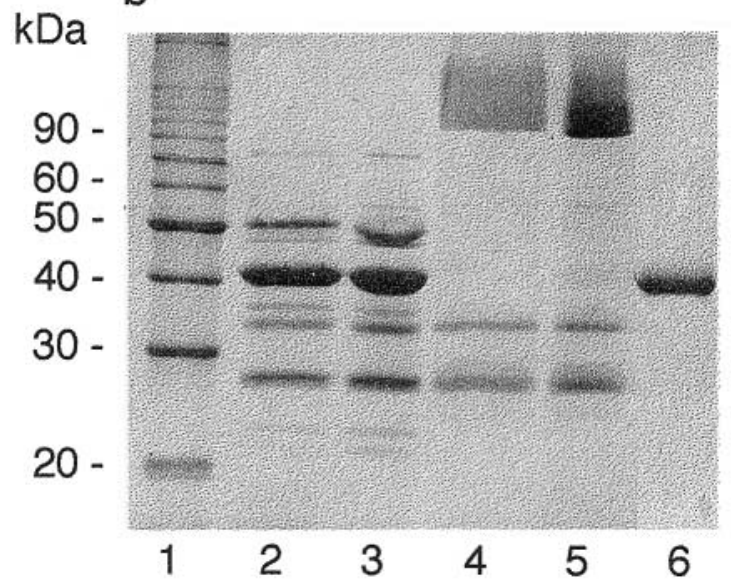

Fig. 3. SDS-PAGE of OMPs from A. caviae isolate Ae398. Mol. wt standards are indicated in $\mathrm{kDa}$ (lane 1). (a) Similar protein profiles were observed when bacteria were grown at $22^{\circ} \mathrm{C}$ for $48 \mathrm{~h} \mathrm{(2)}$ and $37^{\circ} \mathrm{C}$ for $24 \mathrm{~h} \mathrm{(3)}$. (b) Protein profiles after different treatments: OMP in sample buffer with $\beta$-mercaptoethanol (lane 4) and without $\beta$-mercaptoethanol (5); OMPs boiled in sample buffer with $\beta$-mercaptoethanol (2) and without $\beta$-mercaptoethanol (3); purified 43-kDa OMP (6). 
Most proteins were $<60 \mathrm{kDa}$, the predominant band being a $43-\mathrm{kDa}$ protein. This $43-\mathrm{kDa}$ protein was observed only in the boiled OMPs and was not influenced by $\beta$-mercaptoethanol treatment (Fig. 3b). Western blotting analysis revealed specific binding of the biotinylated OMP extract to HEp-2 cells. Only the 43-kDa OMP of A caviae bound selectively to HEp-2 cell surface molecules (Fig. 4).

\section{Adhesion of 43-kDa OMP-coated beads to HEp-2 cells}

Each $1 \mathrm{mg}$ of OMP extract yielded c. $150 \mu \mathrm{g}$ of purified $43-\mathrm{kDa}$ protein. The 43-kDa OMP-coated beads adhered to HEp-2 cells by interacting with the cell surface. The attachment was confirmed by light microscopy (Fig. 5a). Control BSA-coated beads did not interact with HEp-2 cells, even when high concentrations of beads $\left(10^{10}\right.$ beads $\left./ \mathrm{ml}\right)$ were used (data not shown). The 43-kDa OMP-coated beads did not interact with the cell surface when they were pretreated with anti-43-kDa OMP antibodies (Fig. 5b). Similar results were obtained with HEp-2 cells pretreated with OMP extract solution, confirming the specificity of 43-kDa OMP binding to cell surface (data not shown).

\section{Distribution and immunolocalisation of 43-kDa OMP on bacteria}

A uniform distribution of the 43-kDa OMP over the $A$. caviae cell surface was demonstrated by immunogold staining (Fig. 6). The 43-kDa OMP was observed on the cell surface of all the $A$. caviae isolates tested. In the absence of anti-43-kDa OMP antibodies, goldlabelled goat anti-rabbit IgG did not interact with the bacterial cell surface.

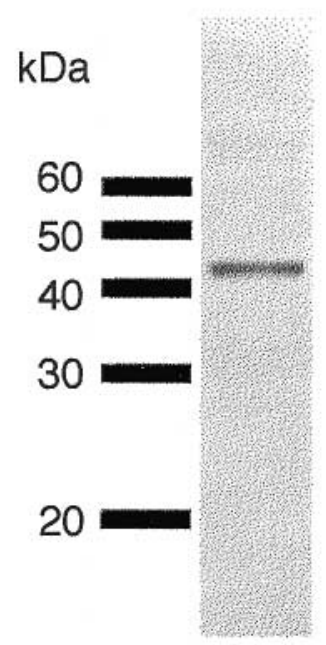

Fig. 4. Western blotting analysis of lysates of HEp-2 cells after interaction with biotinylated OMPs following lysis buffer solubilisation (see Materials and methods) and then stained by the biotin-avidin-peroxidase technique. Specific binding of biotinylated $43-\mathrm{kDa}$ protein to cell surface receptors is shown.
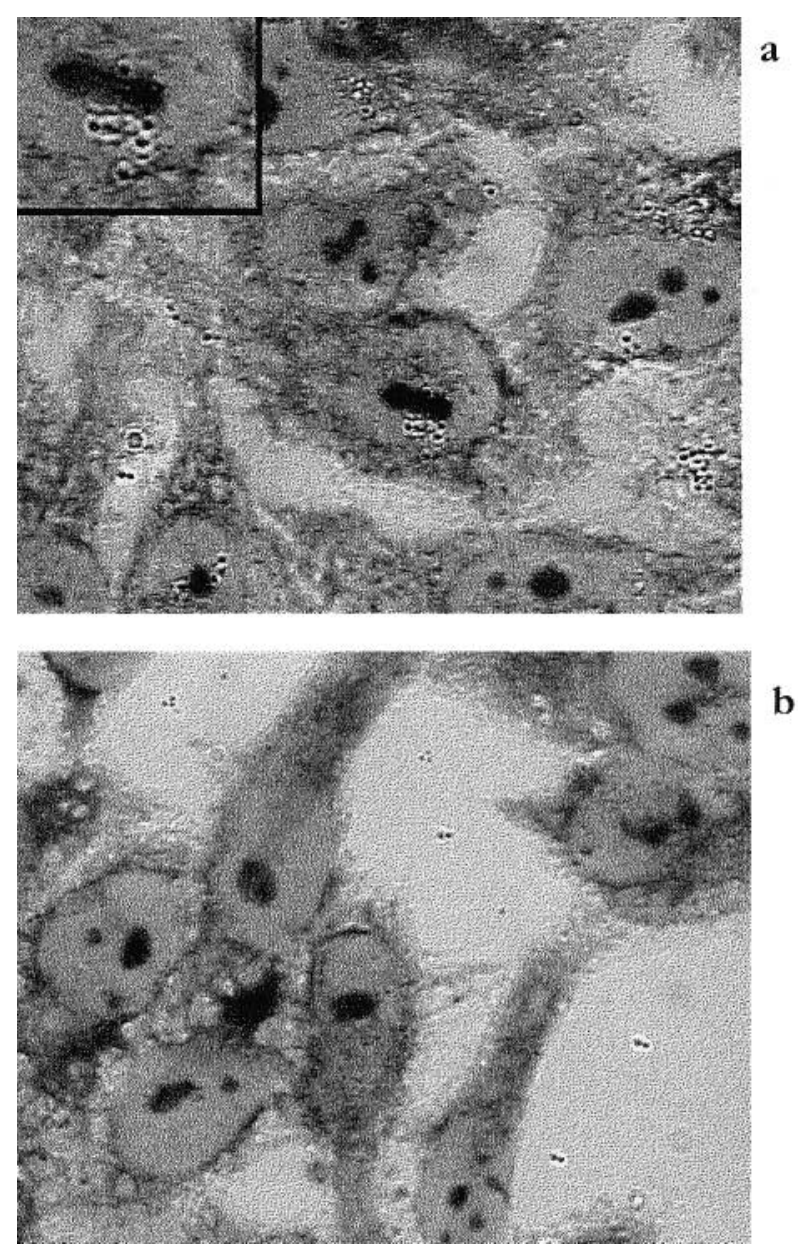

Fig. 5. Light microscopy $(\times 520)$ showing $(a)$ the interaction of $43-\mathrm{kDa}$ OMP-coated beads with HEp-2 cells (inset $\times 1030$ ); (b) inhibition of $43-\mathrm{kDa}$ OMP-coated bead adherence by anti-43-kDa OMP antibody.

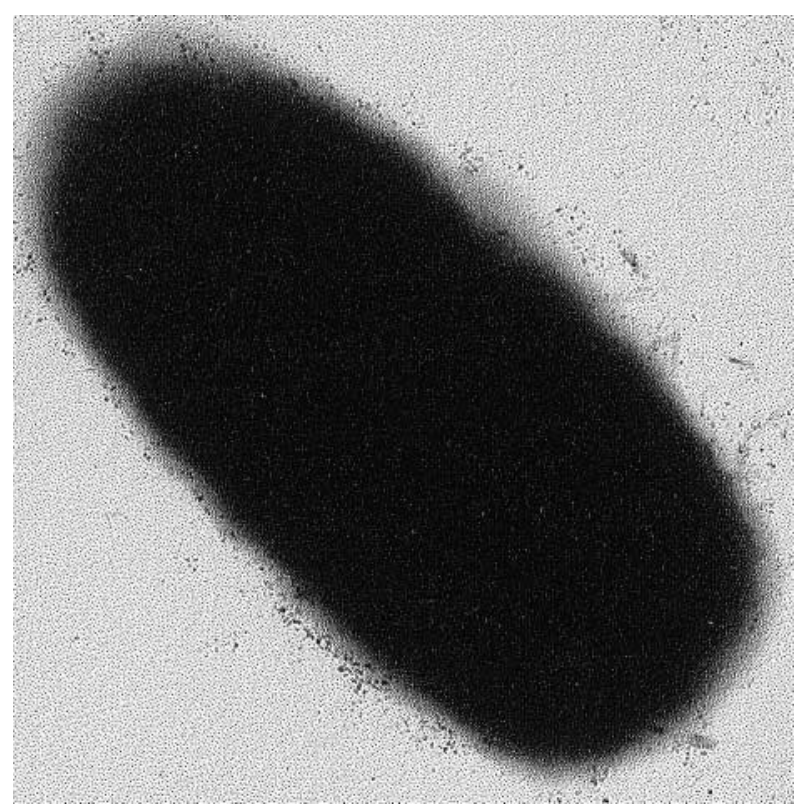

Fig. 6. Immunogold electron microscopy (IEM) of $A$. caviae isolate Ae398, stained with anti-43-kDa OMP antibody. IEM demonstrated a uniform distribution of the 43-kDa protein over the cell surface. 


\section{Discussion}

Although attachment to the intestinal mucosa is likely to be an important pathogenic stage for diarrhoeacausing bacteria, little is known about the adhesive mechanisms of aeromonads. Studies have shown a correlation between bacterial adherence in vitro and infectivity in vivo [10]. Some studies have described adherence of Aeromonas strains to cultured cells such as HEp-2, Caco-2 and INT407 [9, 10, 27]. Although it cannot be assumed that HEp-2 cells, derived from human laryngeal epithelial carcinoma, possess surface receptors identical to these of human enterocytes, a correlation between the high-level adherence to HEp-2 cells and aeromonas enteropathogenicity has been observed $[9,28]$. On the other hand, A. caviae strains were also reported to express weak adhesive properties to HEp-2 cells $[8,28]$. The present study demonstrated that all the $A$. caviae isolates tested showed a high percentage of adherence to HEp-2 cells. The high percentage of isolation of $A$. caviae from children with gastro-enteritis may reflect the enteropathogenic potential of this species. Bacterial growth temperature influenced $A$. caviae adherence to HEp-2 cells and quantitative expression of the 43-kDa OMP on the cell surface. All the A. caviae isolates showed greater adherence when grown at $22^{\circ} \mathrm{C}$ than at $37^{\circ} \mathrm{C}$, as observed similarly with $A$. veronii biovar sobria strains [9]. This difference correlated with higher expression of the $43-\mathrm{kDa}$ OMP at $22^{\circ} \mathrm{C}$ than at $37^{\circ} \mathrm{C}$.

The aggregative adherence pattern was first observed in E. coli strains. Enteroadherent-aggregative (EA-Agg) $E$. coli have been incriminated as important agents of diarrhoea, inducing damage to the intestinal epithelium, and characterised by a shortening of the villi, haemorrhagic necrosis of the villus tips and a mild inflammatory submucosa response [29]. Previous investigations have also described the aggregative adherence pattern to HEp-2 and Caco-2 cells for Aeromonas spp. [11,30]. All the A. caviae strains investigated in this study exhibited the aggregative adherence pattern and readily formed aggregates able to adhere to HEp-2 cells with a stacked-brick appearance.

Filamentous structures were described as colonisation factors in A. hydrophila and A. veronii biovar sobria strains [13]. L/W pili, bundle-forming pili and filamentous networks showed maximal expression under the same conditions $\left(22^{\circ} \mathrm{C}\right.$ for $\left.48 \mathrm{~h}\right)$ as those that induce high adherence to cultured cells $[9,31]$. However, TEM did not reveal the presence of fimbrial structures on the cell surface of highly adherent $A$. caviae strains grown under these conditions. The data suggested that instead of fimbriae, OMPs might be involved in the adherence process. Merino et al. suggested that LPS and OMP might be other important adhesins for binding of Aeromonas strains to HEp-2 cells [15]. The findings of the present study are at variance with that described recently of type IV pili in A. caviae strains isolated from clinical sources in Australia [32], possibly because they are from a different geographic location [6]. Furthermore, it is possible that, if filamentous structures are expressed on the cell surface of $A$. caviae, they exist only in very small numbers under the conditions tested here. On the other hand, adhesion of the Australian A. caviae strains to HEp-2 cells was only in part mediated by filamentous structures [32].

OMPs from A. caviae Ae398, grown at $22^{\circ} \mathrm{C}$ and $37^{\circ} \mathrm{C}$, showed similar protein profiles in SDS-PAGE. The 43$\mathrm{kDa}$ OMP was observed only in boiled extract of OMPs, independently of the presence of $\beta$-mercaptoethanol, indicating either a link of this $43-\mathrm{kDa}$ protein to a heavier molecular structure or its aggregation to other proteins.

A. hydrophila strain A6 was found to produce a haemagglutinin that was inhibited by L-fucose [16]. The haemagglutinin was also described as a poreforming $43-\mathrm{kDa}$ OMP in artificial planar bilayer membranes $[17,33]$. The $43-\mathrm{kDa}$ OMP from $A$. caviae isolate Ae398 may also be a pore-forming OMP. However, none of the A. caviae isolates showed either haemagglutinating activity to human erythrocytes or Lfucose-sensitive adherence to HEp-2 cells (data not shown). Interaction of OMP extract with HEp-2 cells revealed a specific binding of the $43-\mathrm{kDa}$ protein to the HEp-2 cell surface, suggesting that this protein could be an adhesin of $A$. caviae. Furthermore, the $43-\mathrm{kDa}$ OMP-coated beads adhered to the HEp-2 cell surface. The 43-kDa OMP exhibited a uniform distribution over the cell surface of all $A$. caviae isolates tested. Both anti-43-kDa OMP antibody and OMP extract inhibited adherence of $43-\mathrm{kDa}$ protein-coated latex beads. From these experiments, it was concluded that a $43-\mathrm{kDa}$ OMP is involved in A. caviae adherence. Complementary studies are currently in progress to enhance understanding of the role of the $43-\mathrm{kDa}$ protein and other structures in the adherence of $A$. caviae to host cells.

We are grateful to CNPq, CAPES, FAPERJ and SR2/UERJ for providing financial support and to Dr João R.C. Andrade and Dr Maria Cristina M. Plotkowski, Faculdade de Ciências Médicas, Universidade do Estado do Rio de Janeiro for HEp-2 cells, some reagents and helpful comments.

\section{References}

1. Araujo RM, Arribas RM, Pares R. Distribution of Aeromonas species in waters with different levels of pollution. $J \mathrm{Appl}$ Bacteriol 1991; 71: 182-186.

2. Freitas AC, Nunes MP, Milhomen AM, Ricciardi ID. Occurrence and characterization of Aeromonas species in pasteurized milk and white cheese in Rio de Janeiro, Brazil. J Food Protect 1993; 56: 62-65.

3. Gluskin I, Batash D, Shoseyov D et al. A 15-year study of the role of Aeromonas spp. in gastroenteritis in hospitalised children. J Med Microbiol 1992; 37: 315-318.

4. Janda JM. Recent advances in the study of the taxonomy, 
pathogenicity, and infectious syndromes associated with the genus Aeromonas. Clin Microbiol Rev 1991; 4: 397-410.

5. Pazzaglia G, Sack RB, Bougeois AL, Froehlich J, Eckstein J. Diarrhea and intestinal invasiveness of Aeromonas strains in the removable intestinal tie rabbit model. Infect Immun 1990; 58: $1924-1931$.

6. Namdari H, Bottone EJ. Cytotoxin and enterotoxin production as factors delineating enteropathogenicity of Aeromonas caviae. J Clin Microbiol 1990; 28: 1796-1798.

7. Wilcox MH, Cook AM, Eley A, Spencer RC. Aeromonas spp as a potential cause of diarrhoea in children. J Clin Pathol 1992; 45: 959-963.

8. Carrello A, Silburn KA, Budden JR, Chang BJ. Adhesion of clinical and environmental Aeromonas isolates to HEp-2 cells. J Med Microbiol 1988; 26: 19-27.

9. Kirov SM, Jacobs I, Hayward LJ, Hapin RH. Electron microscopic examination of factors influencing the expression of filamentous surface structures on clinical and environmental isolates of Aeromonas veronii biotype sobria. Microbiol Immunol 1995; 39: 329-338.

10. Nishikawa Y, Hase A, Ogawassara J, Scotland SM, Smith HR, Kimura T. Adhesion to and invasion of human colon carcinoma Caco-2 cells by Aeromonas strains. $J$ Med Microbiol 1994; 40: 55-61.

11. Thornley JP, Shaw JG, Gryllos IA, Eley A. Adherence of Aeromonas caviae to human cell lines HEp-2 and Caco-2. $J$ Med Microbiol 1996; 45: 445-451.

12. Hokama A, Honma Y, Nakasone N. Pili of an Aeromonas hydrophila strain as a possible colonization factor. Microbiol Immunol 1990; 34: 901-915.

13. Hokama A, Iwanaga M. Purification and characterization of Aeromonas sobria pili, a possible colonization factor. Infect Immun 1991; 59: 3478-3483.

14. Kirov SM, Sanderson K. Characterization of a type IV bundleforming pilus (SFP) from a gastroenteritis-associated strain of Aeromonas veronii biovar sobria. Microb Pathog 1996; 21: 23-34.

15. Merino S, Camrubí S, Tomás JM. Effect of growth temperature on outer membrane components and virulence of Aeromonas hydrophila strains of serotype O:34. Infect Immun 1992; 60: 4343-4349.

16. Atkinson HM, Adams D, Savvas RS, Trust TJ. Aeromonas adhesin antigens. Experientia 1987; 43: 372-374.

17. Quinn DM, Wong CYF, Atkinson HM, Flower RLP. Isolation of carbohydrate-reactive outer membrane proteins of Aeromonas hydrophila. Infect Immun 1993; 61: 371-377.

18. Freitas AC, Souza SMS, Macedo LC, Pinto EC, Pereira SS. Aeromonas species associated with gastroenteritis in children: prevalence, characteristics and virulence properties. Rev Microbiol 1998; 29: 152-157.
19. Bölin I, Norlander L, Wolf-Watz H. Temperature-inducible outer membrane protein of Yersinia pseudotuberculosis and Yersinia enterocolitica is associated with the virulence plasmid. Infect Immun 1982; 37: 506-512.

20. Markwell MAK, Haars SM, Bieber LL, Tolbert NE. A modification of the Lowry procedure to simplify protein determination in membrane and lipoprotein samples. Anal Biochem 1978; 87: 206-210.

21. Ternynck T, Avrameas S. Techniques immuno-enzymatiques. Paris, Les Editions INSERM. 1991: 108.

22. Laemmli UK. Cleavage of structural proteins during the assembly of the head of bacteriophage T4. Nature 1970; 227: $680-685$.

23. Towbin H, Gordon J. Immunoblotting and dot immunoblotting - current status and outlook. J Immunol Methods 1984; 72: $313-340$.

24. Dias Filho BP, Benchimoli M, Andrade AFB, Angluster J, de Souza W. Purification and immunocytochemical localization of neuraminidase from Trichomonas foetus. Parasitology 1999; 118: $17-25$.

25. Harlow E, Lane D. Storing and purifying antibodies. In: Antibodies: a laboratory manual. Cold Spring Harbor, NY, Cold Spring Harbor Laboratory. 1998: 283-318.

26. Jouve M, Garcia M-I, Courcoux P, Labigne A, Gounon P, Le Bouguénec C. Adhesion to and invasion of HeLa cells by pathogenic Escherichia coli carrying the afa-3 gene cluster are mediated by the $\mathrm{AfaE}$ and $\mathrm{AfaD}$ proteins, respectively. Infect Immun 1997; 65: 4082-4089.

27. Bartková G, Čiznár I. Adherence pattern of non-pilated Aeromonas hydrophila strains to tissue cultures. Micróbios 1994; 77: 47-55.

28. Grey PA, Kirov SM. Adherence to HEp-2 cells and enteropathogenic potential of Aeromonas spp. Epidemiol Infect 1993; 110: 279-287.

29. Vial PA, Robins-Browne R, Lior $\mathrm{H}$ et al. Characterization of Enteroadherent-Aggregative Escherichia coli, a putative agent of diarrheal disease. J Infect Dis 1998; 158: 70-79.

30. Neves MS, Nunes MP, Milhomem AM. Aeromonas species exhibit aggregative adherence to HEp-2 cells. J Clin Microbiol 1994; 32: 1130-1131

31. Kirov SM, Hayward LJ, Nerrie MA. Adhesion of Aeromonas sp. to cell lines used as models for intestinal adhesion. Epidemiol Infect 1995; 115: 465-473.

32. Kirov SM, Sanderson K, Dickson TC. Characterisation of a type IV pilus produced by Aeromonas caviae. J Med Microbiol 1998; 47: 527-531.

33. Quinn DM, Atkinson HM, Bretag AH et al. Carbohydratereactive, pore-forming outer membrane proteins of Aeromonas hydrophila. Infect Immun 1994; 62: 4054-4058. 